\title{
A história em As vítimas do bugre, ou como tornar-se bugre na História ${ }^{1}$
}

Soraia Sales Dornelles*

Resumo: Este artigo tratará da sobreposição em termos territoriais, culturais e políticos dos povos Kaingang e alemães no Vale do Rio dos Sinos, no Rio Grande do Sul, durante meados do século XIX. Das primeiras formas de aproximação entre ambos, desde a observação até o instar-se de um estado de medo compartilhado, que passou a ser fruto de combates reais. Buscaremos explicar as motivações que levaram esses indivíduos às mais complexas situações, que surgiram dessa sobreposição de mundos distintos.

Palavras-chave: História Indígena. Índios Kaingang. Imigração alemã. Bugres. Trajetórias individuais.

\section{Introdução}

Durante o século XIX, o governo imperial brasileiro teve o interesse de colonizar as regiões desabitadas do sul do Brasil e, para isso, tratou de incentivar a imigração de europeus. Na província do Rio Grande, as primeiras levas constituíam-se basicamente de colonos de origem germânica que chegaram a partir de 1824 . A esses imigrantes foram doadas terras tidas como desabitadas, entretanto, eram na verdade territórios ocupados por indígenas do grupo Kaingang, naquela época chamados de Coroados ou Bugres. ${ }^{2}$

\footnotetext{
* Doutoranda do Programa de Pós-Graduação em História Social da Universidade Estadual de Campinas (UNICAMP). Bolsista do CNPq. E-mail: soraiasdornelles@ gmail.com
}

Anos 90, Porto Alegre, v. 18, n. 34, p. 245-278, dez. 2011 
O contato entre indígenas e estrangeiros estava posto: ora surtiram relações amistosas, com estabelecimento de redes de reciprocidade e dependência ora imperou a incompreensão e a violência por ambas as partes. Naquele momento, a questão sobre a presença indígena nas terras disponíveis para o povoamento e colonização do Império era apresentada em diversos meios de discussão, e, a partir disso, os colonos empenharam-se em resolver o problema (MONTEIRO, 2001, p. 170-172).

A partir de 1829 foram registrados os primeiros ataques dos índios Coroados às colônias alemãs. Em 26 de fevereiro daquele ano, na Picada dos Dois Irmãos, pertencente à colônia sede São Leopoldo, “[...] sofreram alguns dos estabelecimentos, que estão mais internados na Serra, uma irrupção dos bugres que além de assassinarem cinco pessoas destruíram quanto encontraram naqueles lugares" . ${ }^{3}$ No relatório do Inspetor da Colônia daquele ano, é possível vislumbrar a rapidez com que foi identificado que os ataques dos indígenas impossibilitariam a eficiência do projeto de ampliação das áreas povoadas e que era preciso proteger aquela empresa. No ano seguinte, o mesmo inspetor reclamava às autoridades que um novo ataque dos indígenas mostrava-se iminente e a dificuldade de formar um destacamento para proteger as colônias não era tarefa simples. ${ }^{4}$

Os assaltos, como eram chamados pelos colonos, repetiramse em 1834 e 1835, no Campo Novo, localizado na primeira légua de São Leopoldo, ironicamente conhecido como "Mortandades", onde, em 1835, morreram oito e ficaram feridos três colonos. Em 1843, os Coroados atacaram a propriedade de Jacó Bohn, no vale do rio Caí, mas foram surpreendidos pelo contra-ataque dos colonos alemães, que tomaram um menino indígena por prisioneiro cuja trajetória será analisada em detalhes adiante. Como características gerais desses assaltos, podem-se observar, em primeiro lugar, o saque às roças de milho que se encontravam prontas para a colheita; por isso, a maior parte das investidas indígenas ocorreu nos primeiros meses do ano. Em segundo lugar, destaca-se a procura por objetos de metais - principalmente o ferro - e tecidos e, por fim, a captura de mulheres e crianças. Aqui, destacaremos as experiências compartilhadas por aqueles personagens que vivenciaram os assaltos de diferentes formas. 


\section{As vítimas do Bugre}

A narrativa do Monsenhor Matias José Gansweidt, ${ }^{5}$ intitulada As vítimas do Bugre, ${ }^{6}$ dá conta de nos transportar para o universo de interação, muitas vezes forçada, entre indígenas e colonizadores. $\mathrm{O}$ único sobrevivente de um sequestro praticado por indígenas, Jacó Versteg, quando já era idoso, retratou sua história ao monsenhor, que escreveu um romance baseado em seu relato e no de outras pessoas que dela participaram. O livro, bastante conhecido na região de imigração alemã, conta em detalhes a história que aqui apresentaremos de forma resumida. Já na abertura do livro observa-se a preocupação dos envolvidos no evento com a veemência dos fatos a serem narrados em seguida: é apresentada a declaração feita por Jacó Versteg, constando estar sua firma reconhecida em cartório:

Com a presente declaração, afirmo que a história que o Cônego Matias José Gansweidt, sob o título "As vítimas do Bugre", escreveu acerca da minha pessoa e dos meus - o quanto me posso lembrar das particularidades - corresponde à realidade, o que afianço com minha assinatura. Poço das Antas, 20 de abril de 1928. Jacó Versteg (GANSWEIDT, 1946, p. 2).

Com esse breve Prólogo, observamos uma riqueza de informações interessantes sobre a obra que nos leva ao personagem Luis Bugre. Há uma clara necessidade de confirmação daqueles que seriam os donos da memória sobre os eventos narrados no livro do religioso. Esse fato pode ser explicado pelo quão extraordinária é aquela história. Tanto para os que a viveram - como o próprio Jacó Versteg e sua família - como para os que dela tiveram notícia - caso do Arcebispo de Porto Alegre, que queria escrever, com as memórias de Jacó Versteg, uma obra digna da Academia Brasileira de Letras. ${ }^{7}$ Os sequestros foram percebidos como fenômenos fantásticos, capazes de chamar a atenção de espectadores e de provocar a defesa da autenticidade de sua participação pelos atores envolvidos.

Outra questão diz respeito ao tempo de dezoito anos que separa o registro em cartório dos documentos anteriormente apresentados 
e a publicação em português de 1946. Também devemos levar em conta o tempo que os manuscritos permaneceram com o Arcebispo. Como destacou Mary Louise Pratt (1999, p. 96), textos publicados muito posteriormente aos eventos que os inspiram têm a capacidade de nos mostrar a força e a potencialidade dessas histórias dentro da cultura oral, dada a circularidade que apresentam. Se mesmo quase vinte anos após a primeira identificação da potencialidade da narrativa, a mesma permaneceu merecendo o estatuto de poder tornar-se um livro, pode-se acreditar que essa história possui grande significado para a comunidade de onde foi capaz de emergir e de permanecer viva. E mais, em outros momentos e suportes, As vítimas do Bugre encontrou lugar para demonstrar tal suposição, como em jornais, por exemplo, quando foi matéria no Correio Riograndense, no ano de 1969, e no jornal O Contexto, em 2009, ambos editorados e publicados na região da serra gaúcha. Ou seja, é absolutamente atual a relevância dessa história para a comunidade, que permanece reafirmando sua identidade sobre fatos que a constituíram, como o sequestro dessa família por indígenas. O livro confronta a ideia divulgada na época - e também pela historiografia que a analisou - de que a imigração se fez sobre terras vazias, e afirma, pelo contrário, que, para quem compartilhou a experiência, "[...] esses mesmos espaços são vivenciados de maneira intensamente humanizada, saturada de história local e significado, [...]" (PRATT, 1999, p. 115).

O Mons. Matias Gansweidt inicia a narrativa buscando fazer apontamentos sobre o contexto da colonização alemã, tendo feito pesquisa documental, como consulta aos relatórios de presidentes de província. A problemática dos ataques dos índios às colônias alemãs é apresentada como principal fator de dificuldade da empreitada em seus primórdios. Gansweidt apresenta um pouco dos aspectos da vida cotidiana da colônia alemã de São Leopoldo, que, desde 1824, era o ponto de partida dos recém-chegados ao Brasil para as novas terras. Disserta sobre como agiam os agentes das empresas colonizadoras, trata também das figuras que viam na nova terra a tentativa de reconstruir suas vidas após falências e infortúnios no Velho Mundo. Igualmente, apresenta a organização das acomodações dos recém-chegados. Deste modo, o autor procura construir um cenário 
realista para apresentar seus personagens, dado que o romance trata de um acontecimento verídico.

Assim é apresentada a nós a família alemã que, mais tarde, tornar-se-á alvo de sequestro pelos índios coroados: Lamberto Versteg, casado com Valfrida Bloom e pai de Jacó, de 4 anos, e Maria Lucila, de 2 anos. $^{8}$ Juntamente com outros companheiros da viagem ao Brasil seguiram em marcha para as terras coloniais (GANSWEIDT, 1946, p. 11). Neste momento da narrativa, o autor trata da "saga" que constituía a travessia da mata pelos imigrantes até a chegada às suas terras. Note-se que, aqui, o autor pode explorar o advento da colonização enquanto um símbolo de coragem e determinação desses europeus. Do mesmo modo, trata dos diversos componentes da rede social que integravam as novas colônias às sedes administrativas. Mesmo que sua narrativa carregue certo exagero quanto a alguns eventos dados na mata, a verossimilhança não é, de modo algum, fantasiosa. Após três dias e meio de caminhada, os colonos chegaram ao local prometido, o sinal era uma árvore descascada na floresta. Entretanto, nada mais havia: nem o agrimensor, seus homens ou outros colonos, muito menos local para abrigarem-se ou mantimentos para saciarem a fome.

Essas narrativas de noites na mata, sozinhos e sem mantimentos, mostram-se constantes nas memórias produzidas sobre os primórdios da colonização, tanto alemã quanto italiana. Reforçam características que, posteriormente, constituirão o próprio ethos do colonizador, tais como a coragem e a perseverança. Por outro lado, revelam a situação real dos mesmos: eram forasteiros que não conheciam nada sobre a nova terra, dependentes dos saberes de outrem; mostram a necessidade que essas pessoas tinham de se abrir para diferentes culturas, tendo em vista sua sobrevivência. Ao chegar na colônia, Lamberto comprou um lote mais ao norte de São Vendelino, no platô do morro; o patriarca teuto tomou informações sobre os afazeres do colono: "[...] arroteamento, frutos que mais rendem, métodos e época de plantar, limpeza da plantação, colheita e modo de vender. Anota como se constrói casa, cozinha, galpão, estrebaria, pocilga, horta e potreiro" (1946, p. 34). Foi ajudado pelo vizinho na construção da casa. Aqui é destacado o caráter rudimentar 
dessas primeiras construções: "Lamberto investe contra a floresta, que recua pela ação pertinaz do machado".

\section{Luís Bugre}

Tratemos, portanto, deste personagem em especial, Luís Bugre. Em 1847, "ano fatídico e sombrio" para muitos moradores da jovem colônia Feliz, ocorreram diversos ataques e incursões dos Coroados. Não apenas devastavam as plantações, mas também lhes pilhavam o gado dos potreiros. Tendo tais acontecimentos como argumento, reuniram-se diversos colonos na tentativa de deliberar sobre a organização da defesa. Desta reunião organizou-se um plano: "Ao primeiro indício dos bandidos, os colonos seriam imediatamente avisados e iriam recebê-los à espingarda: o sal ou os chumbinhos dariam aos brutos uma recordação permanente da recepção que os colonos thes haviam preparado" (GANSWEIDT, 1946, p. 39). Na primeira tentativa dos índios sobre a colônia, especificamente na propriedade de Jacó Bohn, encontravam-se, então, preparados os colonos para o contra-ataque. Uma das partes do plano era esticar cordas nas plantações e a estas fixar latas vazias que denunciariam a presença dos intrusos com o seu ruído. Dado o alarme, o colono iniciou a chamada de todos os vizinhos para que saíssem armados em busca dos invasores. Então,

[...] dispuseram-se rapidamente a linha de ataque. Para impedir a inopinada evasão da horda que de nada suspeitava, cercaram-na em semi-círculo, protegidos pela densa folhagem da mata. Assim também lhes cortavam a retirada. Tudo silêncio. De improviso um grito, logo dezenas de berros de mistura com as deflagrações dos rifles temidos. Alguns cães trazidos pelos colonos, cooperavam no ataque. Indizível o pânico que subjugou os índios. Fugiram tropeçando, caindo, derrubandose mùtuamente qual bando de demônios acossados por água benta. Voaram morro abaixo e no vale se jogaram nas águas tranqüilas do Caí e desapareceram (GANSWEIDT, 1946, p. 39).

Anos 90, Porto Alegre, v. 18, n. 34, p. 245-278, dez. 2011 
Desse fato, decorreu que um menino, de aproximadamente onze anos, atingido no joelho e, dessa forma, inapto para a fuga, tornou-se prisioneiro dos colonos. Esse índio não foi recebido, a princípio, por nenhuma família alemã. $\mathrm{O}$ certo é que, quando estavam quase decididos a devolvê-lo aos seus, foi acolhido como agregado por Matias Rodrigues da Fonseca, de origem portuguesa, mas firmemente integrado à colônia. Dois anos depois, em 1849, foi batizado na religião católica, como Luís Antônio da Silva Lima. O menino foi instruído no português e no alemão, tendo mantido, segundo os informantes, o sotaque sui generis. Mesmo que confusas as informações sobre a criação de Luís, parecem coincidir que o menino não tenha sido obediente ao tutor Matias Rodrigues, mesmo sob a possibilidade de ser castigado,

[...] preferia correr os matos e caçar, no que empregava longas horas do dia. as vezes ausentava-se durante semanas, trazendo, porém, sempre algumas peles de animais bravios. [...] Certa feita desapareceu por vários meses e todos julgavam se tivesse reunido aos de sua raça, quando inopinadamente retornou para junto de Rodrigues. Havia feito uma excursão pelas terras de Santa Catarina, como afirmou. Voltou acompanhado por uma consorte que, no matiz da pele e na estatura, bastante se parecia com ele. Uns dizem que é índia da mesma tribo, outros que é uma cabocla procedente de Portão, no Município de São Leopoldo (GANSWEIDT, 1946, p. 40).

É importante lembrar que Luís havia participado de uma correria quando foi capturado e, portanto, de uma atividade de cunho guerreiro seguindo os parâmetros Coroados de ação. Desse modo, podemos pensar quais significados tiveram sua nova situação, quer dizer, a de prisioneiro entre os brancos, para o próprio menino índio. Em primeiro lugar, podemos pensar em Luís como propriamente um menino? Os Coroados passam a morar sozinhos exatamente na idade em que Luís foi aprisionado e, assim, podemos inferir que sua vida de adulto já estava em curso. ${ }^{9} \mathrm{O}$ mesmo pode-se concluir por sua participação no assalto, bem como por sua independência 
em retornar, quando de sua vontade, à companhia dos seus. Desse modo, o rapaz passou a viver uma experiência especial entre os colonos e a partir dela poderemos acessar, mesmo que de formas indiretas, que sentimentos estiveram em seu espírito e motivaram suas escolhas. Pois é fato que Luís sempre retornou à colônia, mas também sempre visitou seus companheiros nas matas. Não sabemos ao certo a partir de que momento Luís Antônio da Silva Lima passou a ser chamado e conhecido por Luís Bugre. Mas parece-nos interessante tratá-lo assim para que possamos compreender melhor os acontecimentos que cercam sua história.

Nos anos em que permaneceu morando em Feliz, Luís Bugre costumava participar das atividades de caça do colono João Welchen. Correm boatos e discursam alguns documentos ${ }^{10}$ que, nesses momentos, Luís encontrava-se com outros indígenas e que mantinha relações com eles. Assim, Luis Bugre era um intermediário entre os colonos e os indígenas, estabelecendo trocas comerciais de produtos como mel, peles, aves, espelhos, facas de metal, açúcar, sal. Luís também parece ter assumido a função de guia, desde muito cedo, para aqueles que pretendiam incursionar nas matas desconhecidas. Muitas vezes esses imigrantes o acompanhavam e também contatavam com outros índios, tendo conhecido suas casas e aldeias. Aos poucos, vemos ser construída a imagem de traiçoeiro de Luís Bugre, mesmo tendo ele prestado diversos serviços aos colonos.

Frequentemente deixava-se ficar em casa de Matias Theis, no Vale do Tigre, que por camaradagem lhe cedia toucinho, melado ou feijão e outras cousinhas. Certa feita reapareceu e disse a Theis que não se alarmasse, se lá de fora ouvisse um rumor esquisito: seriam apenas seus compadres selvagens que não fariam mal a ninguém. De repente ouviu um cricracrar e ranger de dente em volta da casa, no seu milharal. Não se fiou na palavra do corre-selva e temeu algum assalto traiçoeiro. Como raio, entrou quarto a dentro, pegou da espingarda, voou ao sótão, deslocou uma telha e, pelo telhado, detonou a arma. Quais pássaros espantados, os visitantes fugiram apressados para o mato. Luís Bugre jamais pôde perdoar isso a Theis. Estavam cortadas as relações entre ambos (GANSWEIDT, 1946, p. 41). [grifo meu] 


\section{Soraia Sales Dornelles}

Parecia que o fato de Luís continuar a circular pelas florestas, plantava nos colonos uma desconfiança com relação a sua índole. Depois deste evento, Luís Bugre deixou aquela localidade, dirigindo-se e instalando-se mais ao norte, próximo às nascentes do rio Forromeco, ao pé do Morro da Canastra. Embora tenha sido considerado um traidor por Matias Theis, Luís também sentiu-se traído: sua palavra não foi suficiente para o colono. Desta forma, afastou-se relativamente das colônias. Mas continuou a relacionar-se com seus moradores e com os indígenas nas matas:

Vagueia pela floresta ou visita as vendas destes rincões, trocando objetos, enquanto deixa a mulher e um par de filhos aos próprios cuidados. Em qualquer parte que vá, o acompanha uma forte matilha de cães ferozes que o fazem deveras temido. Menos de uma dúzia nunca o cercam. Mas, justiça lhe seja feita: tem os bichos na mão, atendem prontamente a seu assovio e temem mais sua voz que seu chicote. Conhecendo ele, como a palma da mão, toda a selva ao longe e perto, valiam-se dele os negociantes e ainda se valem para mostras seus artigos aos silvícolas do interior. Isso fazia de muito bom gosto, pois os negociantes em paga lhe davam pinga. Outras vezes servia de guia para os compradores e agenciadores de terras a quem apontava os melhores chãos. [...]. Não quer saber, porém, que o chamem de Bugre. De modo nenhum. Mas Luís Antônio. O epíteto que os brancos lhe deram é um sinônimo de desprezo, uma injúria, uma desonra. Há poucos anos estava uma mocinha ordenhando uma vaca nas cercanias de Salvador [atual Tupandi]. Era Ana Reinehr. $\mathrm{O}$ dia findava. Ouviu ela o patear e fungar de animais. Assustada, virou a cabeça e viu uma corja de enormes cães que avançavam em sua direção e atrás deles, Luís Bugre, armado de um grande fuzil. Sem saber o que fazer, gritou à irmãzinha que além dava de beber a um terneiro guacho: Luís Bugre! Bastou. O selvagem ouviu o nome detestado.

Furioso, arrancou do ombro a arma e, sem tir-te em guar-te, puxou o gatilho. Acertou o alvo: A bala vingativa perfurou o úbere do animal. 
Eis quem é Luis Bugre em alma e corpo, como o conheço por narrativas e de vista. Os meus compadres aqui sem dúvida são capazes fornecer ainda outras notas sobre o herói (GANSWEIDT, 1946, p. 41-42). [grifos meus]

Como pode-se observar, esse breve excerto apresenta uma imensa riqueza de informações acerca do imaginário construído sobre a figura de Luís Bugre. Identificamos uma espécie de arcabouço imaginativo do qual as pessoas se valeram para construir uma ideia sobre este indígena que vivia entre eles. Um homem solitário que percorre distintos universos, que se comunica com eles e, ainda, tira proveito deles, pois tira o que há de mais vantajoso em ser índio, ser colono e ser bugre. Luís Bugre pode conviver com distintas identidades. Entre os colonos alemães, Luís Bugre não conseguiu obter prestígio, mesmo tendo sido-lhes útil e prestativo, parecendo que este permanente contato com seu mundo de origem lhe tornasse indigno da confiança dos alemães. O indígena abominava o nome que recebera, pois percebia o tom pejorativo que o acompanhava. Em um nível mais geral, Luís Bugre representa a existência de margens de mobilidade, que podem alargar as possibilidades de transformação e resistência na sociedade. Para Jacques Poloni-Simard (2000, p. 9397), seguir essas redes egocentradas nos indivíduos permite observar a variedade de identidades com as quais esses se definiam ou eram definidos [exemplo: bugre, colono, kaingang, coroado; colono, italiano, piemontês]. Assim, temos uma fluidez nas categorias, fruto da variedade de laços e círculos de relações compostos pelos indivíduos.

Essa perspectiva depende, é claro, da possibilidade de identificar estes mediadores, que circulavam entre distintos grupos, que conseguiam sair da massa indígena sem cortar os antigos laços de origem; atingiram locais de poder em novos e antigos grupos - caso de Luís Bugre. Esses atores pertenciam a estratos muito distintos da sociedade, o que não significa que o universo colonial era aberto a esta condição. Houve, sem dúvida, um processo de mestiçagem na vida material e social dos povos que estiveram em contato em distintos momentos históricos, que trouxeram mudanças às sociedades indígenas e aos que com elas se encontraram. Entretanto, nem todos os laços devem ser tidos como mestiçagem ou ascensão 
social, quer dizer, era preciso compartilhar certas experiências para que pudessem emergir esses personagens.

\section{O sequestro da família Versteg}

Tendo completado cerca de dez anos que a família de Lamberto Versteg havia se instalado em São Vendelino, em 1868, resolveu ele partir para uma quermesse no Caí, onde iria encontrar seu amigo dos tempos iniciais no Brasil. Como era de costume, Lamberto recebera uma carta do amigo através do ponto comercial mais próximo à sua propriedade, a venda de Eisenbarth. Esses locais, as famosas vendas, constituíam, naquele período, verdadeiros lugares de difusão de informações, pontos de referência e locus predileto das relações sociais nas colônias. Foram nessas vendas que muitas vezes se viu Luís Bugre alterado pela bebida, provocando brigas, como tantos outros o fizeram. Dessa forma, assemelham-se às pulperías, características do universo colonial espanhol, identificadas por Wilde (2003, p. 125) como lugar propício ao contrabando, mas também lugar de encontro e circulação de gêneros e informações.

A primeira coincidência da qual trataremos diz respeito ao fato de que Luís Bugre estava presente no momento em que o proprietário da venda informou a Lamberto a chegada de uma carta endereçada a ele, bem como a respeito de seu conteúdo: os festejos no Caí, e a partida de Lamberto em breve, naquela direção. Tratando-se de viagem curtíssima, Lamberto deixou sua mulher e seus filhos sozinhos; Jacó, que tinha naquela época 14 anos, e Lucila, 12 anos. Partiu juntamente com outros colonos, todos moradores do Forromeco e arredores.

No dia da viagem, em 14 de dezembro de 1867, consta que Luís Bugre fora à propriedade dos Versteg, logo pela manhã, onde encontrou Valfrida e os filhos, e instruiu-lhes para que colocassem um pano branco no telhado, para que os índios do mato não lhe fizessem mal, pois seria esse o sinal de que aquela casa era amiga. Foi o que Valfrida fez logo da partida de Luís Bugre. Mais tarde, no mesmo dia, o rancho foi atacado por um grupo de índios, que os levaram como prisioneiros, além de alguns animais, algumas facas, 
panelas, louças e roupas. Antes de partir, colocaram fogo no que ficara para trás. Quando do retorno de Lamberto, ele encontrou ainda em brasas sua propriedade e percebeu a ausência da família. Notou que se tratava de um ataque de índios, pois na propriedade ficaram as marcas do confronto, dentre as quais, diversas flechas.

(6) Buscou por eles nos vizinhos mais próximos - note-se que essas propriedades distavam um quarto de hora de caminhada entre uma e outra, e, mesmo assim, eram consideradas próximas -, que nada sabiam a respeito. Partiram, então, para São Vendelino, onde tocaram o sino da capela, no intuito de reunir, o mais rápido possível, homens que pudessem socorrer os sequestrados.

No dia 15 de janeiro de 1868, na casa de João Boesing, reuniram-se os componentes da expedição que partiria em busca dos familiares de Lamberto, Matias Rodrigues, enteado de Luís, assumiu a chefia da expedição que partiu na manhã seguinte ao ataque. Tomaram, com o auxílio de cães, o rastro dos fugitivos e seguiram mata adentro (GANSWEIDT, 1946, p. 69). O mais impressionante da narrativa sobre esta parte da história é que esses dias de buscas são apresentados tanto da perspectiva dos expedicionários como também dos sequestrados. Cada detalhe parece coincidir apontando para a veracidade dos fatos. Pode-se perceber os dramáticos instantes em que os Versteg estiveram próximos de serem encontrados. Em dado momento, o grupo de resgate é surpreendido por flechas que vêm da mata. Foram dois dias de buscas, tendo havido intensa chuva em uma das noites. Decidiram desistir quando perceberam que suas provisões e estado físico já estavam próximos de se esgotarem e que a melhor forma de dar continuidade às buscas era chamar à responsabilidade do governo, que lhes prometera segurança, indo até São Leopoldo e exigindo atitudes.

Gansweidt apresenta, então, o que ocorre com os sequestrados. Algum tempo após iniciada a marcha pela floresta, os seus pés encontravam-se gravemente feridos, o que levou os índios a curá-los, ou pelo menos a aliviar-lhes as dores, para que pudessem continuar a fuga o quanto antes. Através de seus métodos, fizeramlhes cortes profundos nos pés e, posteriormente, aplicaram sobre eles brasas e uma pasta de ervas. Também foram utilizados remédios para espantar os mosquitos. Para Valfrida, que é apresentada 
neste momento da narrativa como interlocutora, tratou-se de um momento de grande sofrimento, pois compreendeu como bárbara aquela atitude, e, somente depois de sanadas as chagas, percebeu que se tratava de um remédio. Os prisioneiros foram alimentados e postos sob guarda para que dormissem. Para a mãe: "[...] mais e mais de que os bugres, apesar de rudes e cruéis, sabem ter bons sentimentos e compaixão, o que muito a consola" (GANSWEIDT, 1946, p. 89). Este confronto entre o que esperavam os brancos dos índios é permanentemente marcado nessa narrativa, mesmo que os índios os alimentassem e tratassem de seus ferimentos, parecia iminente o momento em que seriam devorados pelos bugres.

$\mathrm{Na}$ primeira noite, tentaram uma fuga. Valfrida chamou os filhos quando os índios dormiam e iniciaram uma corrida desenfreada pela floresta. O fizeram até a exaustão, quando decidiram descansar em um taquaral; entretanto, foram recapturados. No dia seguinte, reiniciaram a marcha, mas em dois grupos, que seguiram caminhos distintos, provavelmente no intuito de despistar os brancos que os seguiam na mata. Naquele dia ouviram tiros na floresta, que aumentaram as esperanças de Valfrida e as crianças de serem resgatados, mas nada ocorreu. Passaram a noite seguinte em um abrigo devido à torrencial chuva que caiu, a mesma que havia feito com que retornassem os expedicionários. $\mathrm{Na}$ manhã seguinte, após uma curta caminhada, avistaram a aldeia:

Após uns dez minutos de marcha, avista Valfrida ao longe uma espécie de aldeia no cimo de uma leve elevação. É um grande circulo de choças quadrangulares, baixas. No centro ergue-se uma construção mais ampla.

Assalta-a uma onda de alegre esperança: se lá morarem homens brancos, pensa, hei de gritar por socorro, aconteça o que acontecer. Em breve, porém, seus olhos descobrem crianças pardas, nuas, que folgam à sombra de uma árvore; aquilo é pois a taba dos bugres e será, doravante, sua amarga prisão. De fato, é uma aldeia índia, chamada depois "Campo do Bugre". Ficava exatamente no mesmo local onde se ergueria, anos mais tarde, a bela cidade de Caxias do Sul (GANSWEIDT, 1946, p. 101). 
É interessante o fato de a aldeia indígena ter parecido aos olhos da personagem prisioneira com as casas dos colonos. As moradias coloniais dos primeiros tempos em nada assemelham-se com a concepção de cidade que hoje compartilhamos e, muitas vezes, equivocadamente, estendemos ao tempo passado. Logo da chegada dos brancos à aldeia, foram confiados a uma velha índia cujo nome era Ceji. Esta personagem vai mostrando-se aos poucos como uma espécie de líder espiritual do grupo, que detém os conhecimentos da tradição indígena. Essa informação também é apontada por Mabilde ([1897-99] 1983, p. 136) ao afirmar que "[...] essas mulheres velhas serão também encarregadas da guarda e vigia das prisioneiras, quando os homens as possam apanhar". Fatos como esse parecem ter sido corriqueiros, pois outra sobrevivente alemã, a chamada Maria Bugra, informou também ter sido posta, juntamente com os outros sequestrados, sob os cuidados de uma velha índia (KERBER; PADANOV; PUHL, 2007, p. 205).

Voltemos à narrativa de Gansweidt. Após chegarem à aldeia, seguiu-se um alvoroço. Estes foram recebidos alegremente, pois traziam consigo os materiais provenientes do assalto. As roupas foram distribuídas entre as mulheres, o restante - a louça, os metais e os animais - entre todos os outros, e passaram a empenhar-se em preparar uma festa. As crianças logo entrosaram-se com os do grupo, o que também se assemelha a outras situações de sequestro, como nos mostra, mais uma vez, o caso dos Wadenpuhl, no qual "Os dois rapazes, aliás, em pouco tempo se tinham habituado aos costumes dos selvagens e achavam divertida a vida que levavam. Manobravam arco e flecha, trepavam como macacos, subiam as árvores mais altas para colher frutos, ninhos de pássaros, mel de abelhas e uma espécie de cipós [...]" (O 5 de Abril, apud KERBER; PADANOV; PUHL, 2007, p. 206).

No dia seguinte, todos foram acordados pelo barulho que os cães fizeram. Tratava-se da matilha que acompanhava Luís Bugre. Acontece que o índio fora avisar que a polícia estava em busca dos brancos sequestrados e que, portanto, deveriam deixar o local o quanto antes. É nesse momento da narrativa que Valfrida se dá conta da traição de Luís Bugre. Num acalorado diálogo, tenta convencê-lo de ajudá-la e a seus filhos, mas não consegue. Luís lhe diz: "Bugres 
fugir, levar junto mulher branco. Mulher orgulhoso nada mais ser agora que bugre" (GANSWEIDT, 1946, p. 113). Essa frase atribuída a Luís Bugre, contém em si todo o simbolismo presente no título do livro (tanto em alemão quanto na versão em português). Indica a intenção vingativa do indígena, que havia sido feito prisioneiro quando jovem, em devolver aos colonos a mesma experiência. Não cabe aqui discutir se existe, de fato, alguma vítima ou culpado nessa história, mas perceber como, dependendo do lugar em que nos colocamos, todos podem transitar entre os papéis de vítimas e culpados. Entretanto, vitimar Luís Bugre e, com isso, perdoar seu ato de vingança, se é que realmente ele tenha assim pensado, desviaria nosso foco de sua agência enquanto sujeito histórico. Luís certamente ajudou a arquitetar o assalto, teve com isso suas intenções e delas tentaremos nos aproximar. No Campo dos Bugres, iniciaram, pois, os preparativos para fuga, tomaram o que podiam carregar e enterraram ou destruíram o que não pretendiam deixar como vestígio. As mulheres da aldeia condenaram Valfrida por terem de emigrar.

Enquanto isso, tendo falhado a primeira expedição de buscas, Lamberto Versteg e Matias Rodrigues partiram, imediatamente, para São Leopoldo em busca de auxílio do governo. De lá, foram encaminhados para Porto Alegre, onde o governador da Província, Dr. Francisco Marcondes Homem de Melo, deu autorização ao chefe da polícia para que pudesse agir sob a guarda financeira da expedição. No relatório do Presidente da Província de 1868, consta que:

Apesar dos núcleos de aldeamento de índios existentes nesta província não cessaram eles de incursões e estragos nas suas vizinhanças. No dia 14 daquele mês [dezembro] assaltaram os bugres a casa do colono Lamberto Versteg, da colônia de Santa Maria da Soledade, sita no 5 distrito do termo de S. Leopoldo, levando para os matos a família do mesmo colono, composta de mulher e filhos. Tão depressa tive conhecimento desta triste ocorrência, autorizei o Dr. Chefe da Polícia a andar proceder as necessárias diligências com o fim de afastar os bugres para longe das colônias e de reaver a família raptada. ${ }^{11}$ 
Assim, o Chefe da polícia recrutou voluntários entre os próprios colonos e, em 22 de janeiro de 1868, dezoito homens reuniramse na casa de Eisenbarth no Forromeco. Entre os membros da expedição, estava Luís Bugre. Este apresentou-se aos colonos e ao delegado como um membro importante para o sucesso da expedição, visto que conhecia as matas e os índios. "Luís Bugre mostra-se admirado e aparenta indignação pelo assalto execrado dos bugres" (GANSWEIDT, 1946, p. 117). Assumiu, pois, a função de guia da coluna. O que Gansweidt tenta nos mostrar, coerentemente com os fatos, é que, para o índio, o ponto principal era não permitir o salvamento dos desaparecidos, tendo em vista que esses poderiam denunciar sua participação no assalto.

Nos primeiros dias, pouco aconteceu. O fato mais relevante foi o ataque que os expedicionários sofreram de um bando de porcos do mato. Em seguida, Luís Bugre os levou ao agora abandonado campo de pinheirais. Lá, todos puderam observar os traços do que, sem sombra de dúvidas, fora uma aldeia: cinzas de fogueiras, os buracos dos postes que constituíam as estruturas das moradias, as palhas secas que eram prováveis telhados. $\mathrm{O}$ abandono mostrou-se recente. E, por outro lado, a exagerada indignação de Luís, chamou a atenção do delegado. Assim, a tropa, desconfiada, decidiu despistar Luís, solicitando que retornasse para procurar uma bolsa de moedas perdidas no último local de pouso, mas, na verdade, fizeram isso para continuar a marcha sem ele. Dessa forma, chegaram à propriedade do estancieiro Manoel Firminiano, onde se refizeram e ainda ganharam como reforço os peões do proprietário. Continuaram as buscas, entretanto, dez dias depois retornaram todos à fazenda sem nenhuma notícia ou sinal dos desaparecidos. Sobre o final da jornada, informa-nos o mesmo relatório anteriormente referido:

Por ofício de 24 de fev., comunicou-me o Chefe de Polícia que foram infrutíferas as diligências empregadas, pois apenas se encontraram vestígios passageiros da marcha dos selvagens, despendendo-se com a partida que de 19 de janeiro até 11 de fevereiro se internou nas matas, a quantia de $701 \$ 740$ réis que mandei pela diretoria da fazenda provincial. ${ }^{12}$ 
Findada essa segunda expedição em busca de sua família, Lamberto Versteg perdeu as esperanças e vendeu seu rancho em São Vendelino, partindo sem que os outros colonos tomassem conhecimento de seu destino. Também as notícias sobre Luís Bugre escassearam por algum tempo. Enquanto isso, permaneceram os três colonos sob a guarda dos indígenas. Dentre a densidade de informações que Gansweidt apresenta, é relevante tratarmos de alguns aspectos que podem nos ajudar a compreender esse período vivenciado pelo grupo ao qual os três colonos somaram-se. Tenhamos, portanto, em vista, que essa se trata da única forma de acesso à experiência vivida por aqueles protagonistas cujo relato coube ao sobrevivente alemão, Jacó.

O certo é que, durante praticamente dois anos, aquele grupo circulou pelo território de matas do nordeste do Estado (GANSWEIDT, 1946, p. 141-167). Esta circulação pelo território era comum ao grupo, pois nos meses de inverno se dedicavam à coleta de pinhões nas zonas altas e, no verão, praticavam a caça em áreas de planície. Entretanto, com o início da colonização, os espaços ficaram cada vez mais reduzidos. Não era raro que avistassem, ao longe, traços da colonização. "Lotes de gado, variado na cor, e tropas de cavalos pastam em alguns pontos. De espaço em espaço alvejam sobre o verde capim, algumas moradias de civilizados, rodeados de árvores frutíferas". E ainda, “[...] ouvem ao longe latidos, mugidos e cocoricós. Logo, espalhados por lá moram colonos, os caras-brancas que eles tanto odeiam" (GANSWEIDT, 1946, p. 180, 197).

Nessas aproximações, era destacado um grupo que caía de assalto às plantações e roças de mandioca dos colonos (1946, p. 200). Em uma dessas expedições, um homem voltou ferido, fato este que provocou a expectativa de vingança entre os membros do grupo. Partiram novamente em direção à mesma roça, mas lá estavam os colonos à espera de um novo ataque dos índios, preparados com armas e cães. Surpreenderam, assim, aos índios que fugiram e partiram novamente em marcha daquela região. O destino, dessa vez, foi a antiga aldeia. Conforme Mabilde ([1897-99] 1983, p. 159180), depois da instalação da política de aldeamento pelo Estado, da colonização europeia e do acirramento das guerras internas entre os Coroados, a alta mobilidade dos grupos que optaram pela 
permanência nas matas foi estimulada, pois aqueles índios se viam perseguidos por diversos grupos e, desse modo, não tinham mais condições de manter alojamentos permanentes, como confirma o relato de Jacó nas palavras de Gansweidt.

Enquanto Valfrida é apresentada pelo narrador como permanentemente reminiscente de sua vida na colônia, enfraquecida com o passar do tempo, os filhos aparecem adaptados ao modo de vida do grupo do qual faziam parte naquele momento,

\begin{abstract}
A exceção de leves tosses e alguns resfriados, estiveram sempre bem dispostos e participavam voluntários nos feitos e afazeres dos colegas. Aprenderam termos e frases da nova língua. A breve trecho identificaram-se, quase completamente, com os jovens selvagens. E por tais passariam se não fossem as roupas, todo enegrecidas e com rasgões, através dos quais a alvura da pele denunciava serem de outra raça (GANSWEIDT, 1946, p. 148).
\end{abstract}

As duas crianças eram permanentemente instruídas pela velha índia, que lhes contava várias histórias sobre como viviam os Coroados. Jacó parece inclusive ter sido agraciado pela afeição do cacique do grupo. Participou de caçadas, embora a coleta de alimento pareça ter sido sua tarefa mais comum.

É o próprio Gansweidt que questiona os pontos mais interessantes a serem debatidos: "Mistério para Valfrida! Que tencionavam fazer dela e dos filhos os bizarros selvagens? Simples prazer em possuir brancos em seu meio? Vingança premeditada contra os colonos? Ou algum plano mais ousado, mais incrível: talvez queiram fazer do Jacó, no futuro, um morubixaba que os conduza a uma guerra de extermínio contra os estrangeiros?" (GANSWEIDT, 1946 , p. 165). Nenhuma das suposições pode ser tomada como absurda, nem mesmo esta última, pois sabe-se que um cacique "de fora" era possível entre os Coroados, mesmo constituindo uma exceção. Por exemplo, a tribo do cacique Nicuó (ou João Grande, como era conhecido entre os brancos), que se tratava de um grupo dissidente do cacique Braga. Naquele momento (1850-1853), o grupo encontrava-se numericamente reduzido - 23 indivíduos, 
dos quais apenas duas mulheres - e era capitaneado por um negro foragido da fazenda de Mariano Pimentel nos Campos de Vacaria, que, desse modo, podia indicar os locais para assaltos, por conhecer as rotinas do lugar (MABILDE, [1897-99] 1983, p. 42-43, 60-61). Como discutiu Laroque (2000), existem controvérsias na bibliografia a respeito da origem étnica desta liderança, pois no relato de Leopoldo Petry $(1923 ; 1931)$ Nicuó era o negro fugido e no momento de sua morte, "[...] atingido por um varapau de Yatoahê (Doble)" (LAROQUE, 2000, p. 141), teve seu crânio analisado e daquele modo verificada sua origem negroide, por constatarem ser "muito duro". Já em uma correspondência de Felipe José de Souza ao presidente da província, temos a informação da morte e do extermínio do grupo de João Grande, bem como de um escravo fugido tido como desconhecido. ${ }^{13} \mathrm{O}$ fato mostra a possibilidade de um "estrangeiro" poder constituir um grupo Coroado de modo a, inclusive, ocupar uma posição de liderança.

Outro cacique que teria descendência não coroada seria Nonohay. De acordo com a narrativa do cacique Konkó ao coronel Serafim de Moura Assis, relatada em 1930 (ROSA, 2009), ${ }^{14}$ no ano de 1752, uma expedição saída de São Miguel das missões, comandada por D. Miguel de Aguilar e D. Alejandro Martinez (ambos brancos), conduziu um grupo Guarani que deveria buscar erva-mate. Tendo penetrado nas proximidades do rio Inhacorá, foram atacados por um grupo de Coroados. Muitos guaranis padeceram, bem como D. Alejandro, entretanto, D. Miguel foi capturado. Entre os Coroados, passou a ser chamado de Fondengue e a compartilhar seu modo de vida, dando prova de sua lealdade em um combate que seu grupo manteve contra os Botocudos, por ter avisado do perigo ao seu cacique. "Feliz em poder contar com este bravo homem, Tandu [cacique do grupo a que se uniu D. Miguel] nomeou-o seu substituto no comando do aldeamento e o presenteou com mulheres das mais bonitas da tribo como esposas" (ROSA, 2009, p. 142). Como cacique dos Coroados da região da Guarita, em 1772, Fondengue convocou dois de seus filhos para que combatessem os Botocudos: Ming (tigre) e "o filho sem nome". Este último possuía uma esposa guarani que partira com ele para o combate. O filho sem nome, ao ser atingido durante a luta, caiu ao chão e ficou inconsciente. Sua mulher, 
que falava mal a língua dos Coroados, gritou "nonohay" - conforme Mendes, "[...] dormindo ferido -, de forma errada, dando o nome ao filho de Fondengue ali mesmo: "Nonohay". "Isso aconteceu porque os demais guerreiros julgaram que a palavra pronunciada pela guarani fez reviver o jovem índio" (ROSA, 2009, p. 143).

Assim, de acordo com a análise de Rosa sobre as histórias contadas pelos Kaingang em distintos momentos da história, mostram que a narrativa sobre o passado deste grupo relaciona-se com as guerras e a vingança, mas também com a mestiçagem, como constituinte da configuração étnica deste grupo (2009, p. 158). Segundo as informações coletadas pelo autor, não só Nonohay teria casado com uma Guarani, mas seria, ele mesmo, filho de uma relação também mestiça, isto é, entre um branco e uma kaingang. O que se deseja com esta breve apreciação é mostrar como as possibilidades de indivíduos exógenos ao grupo assumirem papéis na sociedade coroada não configuram um absurdo, mas sim uma possibilidade plausível conforme a história e a memória deste grupo.

Voltemos, pois, ao sequestro da família Versteg. De volta à aldeia no Campo dos Bugres, segundo Gansweidt, os índios iniciaram os preparativos para uma guerra aos Coroados do Norte. Conforme Jacó, a inimizade era fruto de uma "festa em tempos remotos" da qual "até hoje não se estancaram as hostilidades". Com os fatos ocorridos desde o último confronto, isto é, o roubo dos brancos e a fuga da aldeia, o contra-ataque ficara para segundo plano e, de acordo com o autor: "De modo algum. A natureza selvagem dos índios não lhes consente olvidar uma afronta ou deixar de exercer uma represália" (GANSWEIDT, 1946, p. 243). Gansweidt narra desde o convencimento dos anciãos pelo cacique, os preparativos, até a angústia das mulheres no aguardar a volta dos seus. Contudo, deveriam preparar-se para o contra-ataque dos inimigos do Norte, muito em breve. Sua confiança na vitória provinha, principalmente, das armas obtidas nas trocas com Luís Bugre, como facas e punhais. Em torno de um mês, deu-se o novo combate. A riqueza de informações nessa parte da narrativa é surpreendente, sendo contemplados vários pontos cruciais sobre a prática da guerra entre os Coroados: como prepararam o campo para a batalha, construindo uma "fortaleza" para guardar as mulheres; como se deu o ataque 
dos Coroados do Norte, que fizeram alianças com outros grupos e atacaram em número maior que os do Sul, além de usarem cães; o uso estratégico das lâminas, quando a guerra parecia estar ganha pelos do Norte; e, finalmente, a fuga para o mato dos do sul. O final do incidente resolveu-se em um duelo entre os guerreiros, em que venceram os do sul.

O primeiro ponto a ser aqui analisado diz respeito à indicação do motivo que conduziu o grupo à guerra, isto é, a inimizade que se iniciou em uma festa no passado. A vingança, conforme as informações tomadas de Alphonse Mabilde, realmente motivava os ataques entre os grupos Coroados que mantinham inimizades de longa data, bem como renovaram-se e inventaram novas inimizades no contexto do século XIX. Portanto, tendo em vista os locais por onde Jacó Versteg circulou, juntamente com os Coroados, durante o período que deles foi prisioneiro, podemos inferir seguramente que se tratava do território sob domínio de caciques inimigos de Braga, de acordo com o que atesta Mabilde ([1897-99] 1983, p. 162). Em segundo lugar, destaca-se a importância cabal dos objetos de metal conquistados nas correrias e trocas efetuadas com os intermediários. Mais uma vez, o ferro apresenta-se como a verdadeira obstinação dos índios, por lhes garantir maior eficiência em suas guerras ou na obtenção de mulheres para desposarem (DORNELLES, 2011, p. 45-47). Desse modo, podemos afirmar que a real causa dos assaltos ou correrias praticados pelos Coroados, no século XIX, não se relacionava com uma suposta "reconquista territorial", como muitas vezes atribuiu-se a tais ações, mas a obtenção de objetos de prestígio simbólico e, ao mesmo tempo, aplicabilidade a finalidades práticas de suas vidas. ${ }^{15}$

A consequência daquela guerra foi a morte de muitos índios, dentre os quais, Ceji, a velha índia que cuidava dos prisioneiros. Também relegou-lhes a destruição completa da sua aldeia no Campo dos Bugres. Após este evento, escolheram um novo cacique, que se tratava do filho do anterior. Desses dois fatos, parecem decorrer as transformações da situação dos prisioneiros. Do primeiro, a morte da velha índia, deriva o fim da proteção que mantinham até então, principalmente as mulheres. Do segundo, a posição de Jacó, que é predileto pelo novo cacique como candidato a ocupar um lugar de 
poder (GANSWEIDT, 1946, p. 287). A sucessão entre os Coroados era, naquele período, hereditária, cabendo ao novo cacique geral a nomeação de seus próprios subordinados e a redistribuição das mulheres desposáveis. Como apresentamos anteriormente, não seria absurdo pensar que Jacó Versteg pudesse ter conquistado prestígio entre o grupo e tornado-se uma opção como liderança (MABILDE [1897-99] 1983; LAROQUE, 2000; DORNELLES, 2011). Mas não foi o que aconteceu.

$\mathrm{Na}$ narrativa de Gansweidt, Valfrida e Lucila, durante uma ausência de Jacó, tramavam uma fuga, quando tiveram seus planos descobertos por, nada mais, nada menos, que Luís Bugre. Daí decorre o fato de Valfrida ter sido morta, e Lucila, ter passado a cumprir atividades mais duras como escrava das índias. Sobre a veracidade desta parte da história, existem diversas dúvidas, pois, em outras narrativas, ${ }^{16}$ Valfrida tem outro fim. Em algumas, é trocada com outro grupo em que é entregue para desposar um indígena. Também aparecem versões distintas de sua morte: teria sido por fraqueza ou melancolia, em outras, confirmam a morte violenta por traição. As mesmas especulações fazem-se sobre a irmã, que desapareceu tempos depois da mãe. Entretanto, esse suposto "desaparecimento" das mulheres pôde ser verificado também em outros relatos de sobreviventes dos sequestros, como o relato de Carl Harras. Ao conseguir fugir dos indígenas, contou ao pai sobre a mãe que:

[...] quase sempre éramos mantidos afastados um do outro, para não nos podermos falar. Não me lembro mais bem, quando, onde e como a vi pela última vez. De repente tinha desaparecido. Não sei se ficou atrás por fraqueza, morrendo, ou se foi morta a golpes de tacape. Eu me prestava para tudo aparentando contentamento, brincava e jogava luta com os guris dos bugres, ganhando a sua confiança, coisa que favoreceu e facilitou a minha fuga (F.W. 1913, apud Becker, 1995, p. 310).

Assim, a partir daquele momento, com o desaparecimento da mãe e da irmã, a fuga tornou-se o objetivo de Jacó. Este sentiuse muito seguro e confiante, pois após quase dois anos, pensava 
dominar como qualquer outro indígena a mata e o modo de vida dos Coroados. Dessa forma, escolheu um dia de festa para efetuar seu plano. Como de costume, fez parte do grupo de caça que estava destacado para preparar o banquete, tarefa que realizou com o afinco e gosto de costume. $\mathrm{Na}$ noite do grande evento, acompanhou os festejos até que estivessem todos dormindo do cansaço das danças e encenações. Aproveitou, então, esse momento para desaparecer na mata. Passou quase toda a noite em marcha, mas obrigou-se a descansar; assim que despertou, reiniciou a busca de socorro, encontrando sinais de animais domesticados em terreno pantanoso. "Para iludir seus eventuais perseguidores, vira-se e avança de costas até ultrapassar a terra mole. Recomeça então o trote, alegrando-se com a descoberta de sempre novos sinais que o gado por aí deixou no seu vagar pelo mato" (GANSWEIDT, 1946, p. 292). Essa mesma estratégia, isto é, a busca pelos caminhos de gado como referência, e até mesmo a ladinagem ao fazer pegadas enganadoras, aparece no relato de Maria Bugra ao tratar de sua fuga:

Maria, satisfeita com a licença obtida, dirigiu-se para o interior do mato, procurou os rastros do gado e seguiu-os, correndo o quanto podia. Às vezes encontrava, em terreno solto, profundos trilhos de animais, e nessas ocasiões usava da precaução de seguir com as costas para frente, afim de melhor iludir os bugres [...] (O 5 de Abril, apud KERBER; PADANOV; PUHL, 2007, p. 207).

Mais tarde, no mesmo dia, Jacó escutou o latido dos cães e aumentou, ainda mais, a ansiedade de encontrar compatriotas. Mas, naquele momento, percebeu a aproximação dos bugres a perseguilo. Por um instante, pensou ter falhado sua fuga, mas usou de todas suas forças para cumprir seu objetivo: àquela altura, nada lhe importava, somente o desejo de reencontrar o pai. Correu o máximo que pode. Os peões pensaram estar, como era de costume, sob o ataque de índios, e tomaram suas armas para defesa. Mas, ao ouvirem os gritos de socorro de Jacó, compreenderam a situação e passaram a afugentar os perseguidores, que voltaram para o mato de onde, 
inutilmente, lançaram suas flechas, sem resultado algum. "Jacó está salvo" (GANSWEIDT, 1946, p. 294).

O jovem fora resgatado pelos homens do rico estancieiro português Adolfo Pacheco. Quer dizer, Jacó encontrava-se nos Campos de Cima da Serra. Rapidamente correu a fantástica notícia de que fora encontrado "um bugre". Na fazenda onde foi acolhido, recebeu os primeiros cuidados: deram-lhe banho, roupas novas, alimentaramno. Na narrativa, são diversas as percepções dos portugueses quanto aos modos "selvagens" do rapaz, mas, independentemente disso, todos se afeiçoam dele, principalmente os filhos do estancieiro, que o seguiam a todos os cantos. Jacó os ensinou a "[...] fabricar flechas e arcos. Treina-os em corridas. Vai com eles colher frutas silvestres" (1946, p. 297). Aos poucos, aprendeu português e passou a constituir parte daquela família, dos quais recebeu carinhos como um verdadeiro filho. Entrementes, dali a um mês, um tropeiro alemão de nome Cristóvão Horn ali chegou, como de costume, para buscar gado para abater em São Leopoldo e Taquara. Apresentou-se, pois, a oportunidade de todos saberem a história de Jacó. "O tropeiro que soubera do assalto dos bugres à família Versteg, não cabe em si de surpresa, ao descobrir por estas bandas o único sobrevivente das torturadas vítimas" (GANSWEIDT, 1946, p. 297).

Trocaram informações sobre o ocorrido: das expedições de resgate, das desventuras na floresta. O tropeiro falou sobre terem ido até a aldeia deserta, do que Jacó contou sua versão, sobre a fuga pela mata. Falou sobre tudo o que passaram. Ficou sabendo o que fizera o pai desolado e que não sabiam onde se encontra. Mas apesar disso, decidiu partir com Cristóvão Horn, mesmo tendo recebido a proposta de ficar entre os Pacheco, como filho de direito, mas não pôde o jovem deixar de procurar o pai. Partiu, recebendo, de presente, um cavalo, para poder dirigir-se a São Leopoldo e iniciar as buscas. Já em São Leopoldo, confirma a venda do rancho pelo pai a Antônio Zêni. Começou a investigar nas vilas vizinhas, mas manteve-se em São Leopoldo, junto à família de Felipe Keller. Frequentou a escola e trabalhou. Por volta de seis meses depois do retorno, ao caminhar próximo ao rio dos Sinos, observando o trabalho de homens a descarregarem farinha de uma lancha, reencontra o pai que ali trabalhava como estivador. "Homem e moço 
cruzam os olhos e, soltando um grito, caem nos braços um do outro" (GANSWEIDT, 1946, p. 303). Deste modo, compartilharam suas histórias de sofrimento e partiram juntos. Lamberto Versteg havia se colocado como marujo numa companhia de navegação fluvial, à qual também se uniria Jacó, até a morte do pai. Depois disso, Jacó voltou para São Vendelino, onde casou-se com Carolina Weirich, com quem teve treze filhos.

Fica para nossa imaginação a possibilidade de talvez, um dia, Luís Antônio da Silva Lima ter reencontrado sua família, seu pai, e ter tido com ele um momento como teve Jacó. E quantas outras aproximações a experiência de Jacó pode nos fazer refletir sobre a vida de Luís: se ele também pensou que os alemães o matariam quando foi capturado; se gostou de aprender brincadeiras e tarefas com os colonos; se as comidas estrangeiras lhe deram prazer; qual dificuldade teve o indígena com a língua alemã e o português. Infelizmente, não se pode confirmar nenhuma dessas especulações, mas esse exercício de comparação devolve a Luís um pouco da sensibilidade para encontrarmos algum significado em sua experiência tão ímpar. O que ocorreu com Jacó Versteg depois de tudo isso suscita nossa problematização:

Jacó era alegre e expansivo por natureza. Muito sociável. Mas homens sem coração, sempre prontos para rir-se em vez de compadecer-se das dores, lançam-lhe frequentemente em rosto o fato de ter estado entre os brutos e o rebaixam, zombateiramente. Com ironia o apelidam de "Jacó Bugre" com que pretendem achincalhá-lo. A isso vêm acrescentarse, num jornal teuto, calúnias injuriosas assacadas à sua mãe, tida como ainda viva, por aquele período. Tanta descaridade e maldade fere fundo a fina sensibilidade do coração de Jacó. Em consequencia disso, começa a fugir da sociedade, retrai-se, ensimesma-se. Evita falar nos acontecimentos de sua juventude, nos tempos em que conviveu com os bugres (GANSWEIDT, 1946, p. 205).

Como mesmo indica o autor, Jacó tinha-se transformado em bugre. O mesmo ocorrera com Maria Wadenpuhl, Carl Harras, 
Frederico do Bugre e Luis Antônio da Silva Lima e, talvez, outros tantos de que não pudemos tomar conhecimento. Quais expectativas e medos compartilharam? Será possível pensar uma categoria especial para essa experiência? Seria esse um ponto significativo de investigação? Acredito que se existe uma forma de compreender esta conjuntura em sua estrutura, elegeremos o termo bugre para congregar um emaranhado de significados. Após a chegada de Jacó Versteg a São Vendelino, Luís Bugre afastou-se de lá e instalou-se mais ao norte da serra. Provavelmente, por estar ciente que Jacó revelaria a todos sua participação no sequestro, como, de fato, o fez.

\section{Como se fazem bugres na História}

Neste artigo, buscamos discutir as relações entre a História e o livro As vítimas do Bugre, fruto das relações de contato de Coroados e alemães que a tornaram possível enquanto discurso, memória e História. Tudo a seu respeito mostra-se revelador: escrito pela primeira vez em 1929, por um padre alemão, e publicada em português em 1946, recuperava pelo menos um século de interações e conflitos entre indígenas, imigrantes, religiosos e governo. É a partir desta perspectiva que buscamos refletir sobre as experiências compartilhadas por personagens cujas vidas se cruzaram no contexto de colonização europeia do Rio Grande do Sul no século XIX. Deste modo, a obra de Gansweidt nos possibilita observar a complexidade destas relações e, mais, permite vislumbrar as redes históricas entrelaçadas em discursos e experiências pessoais. Conforme observamos, não há dúvida sobre a história que está contida em As vitimas do bugre. E a preocupação de nossa testemunha ocular, Jacó, que fez questão de autenticar em cartório sua assinatura sob o livro, como mostramos anteriormente, também quer nos afirmar isso. Mas o que esta obra produziu em termos historiográficos até o presente momento? Certamente, não foi capaz de evidenciar o protagonismo dos agentes indígenas nesse processo, pois ainda permanecem à parte da construção da história oficial na região, que prioriza a participação da imigração europeia. No caso da colonização alemã, não se pode negar o reconhecimento daqueles 
encontros por parte dos meios intelectuais, mas esse contato foi apresentado apenas a partir dos conflitos, sem buscar explicá-lo em sua complexidade, cabendo aos indígenas a figura de selvagens e assassinos que agiam de forma irracional.

O livro carrega em seu título também um tom intrigante e explicativo sobre o contexto em questão. Quando observamos a existência de vítimas, reportamo-nos também à existência de culpados, neste caso, o Bugre. Torna-se importante lembrar que esta história, se tivesse sido escrita pelo Arcebispo Dom João Becker, poderia ter tido outro nome, Duas Culturas, conforme explicou Monsenhor Gansweidt. Ou seja, há, pelo menos, duas distintas interpretações sobre os fatos. Se para o Arcebispo a distinção de culturas constituía a essência do que se passara, Gansweidt dava primazia ao fato individualizante da mesma, os alemães eram vítimas do traidor Luís Bugre. Temos, em um primeiro momento, alemães e Coroados como formas culturais distintas e, em outro, uma espécie de fruto daquele encontro marcado pelo ato do Bugre, em que sua agência, mesmo acenada, era pejorativa, indesejada e incompreendida. Mas, então, o que significava ser bugre?

A palavra "bugre" foi utilizada no Brasil, em diversos lugares, para designar os indígenas de distintos grupos por serem considerados arredios, não dispostos aos projetos de catequização e, posteriormente, de civilização implementados pela administração da colônia e do império. De acordo com o dicionário Honaiss da Lingua Portuguesa (2009, p. 336), a origem da palavra vem do francês bougre, possuindo o primeiro registro no ano de 1172, que significa "herético", que por sua vez possui origem latina medieval (século VI) bulgàrus. Como membros da igreja greco-ortodoxa, os búlgaros foram considerados heréticos, e o emprego do vocábulo para denotar a pessoa indígena liga-se à ideia de "inculto, selvático, não cristão" - uma noção de forte valor pejorativo. No Brasil, a data do termo, segundo a mesma fonte, é $1877 .{ }^{17}$

Limitar-me-ei a tratar aqui dos usos do termo na Província de São Pedro do Rio Grande do Sul. Alphose Mabilde identifica o chamamento bugre como uma forma de diferenciação dos Coroados dos indígenas do grupo Guarani, também em outras províncias. $\mathrm{O}$ engenheiro especulava que a expressão poderia ter surgido da 
má compreensão por parte dos exploradores de um grito agudo de guerra desses indígenas, a palavra pucri, prolongando a letra $i$. Mabilde ainda afirmava:

Sem significação direta traduzível, esta palavra só serve para aquelas ocasiões e tem para eles o mesmo valor que terá para nós a palavra ALERTA, substituída por um grito convencional qualquer. É, pois, fácil, da palavra "pucri”, articulada da maneira explicada, entender-se a palavra bugri ou mesmo bugre ([1897-99] 1983, p. 07-08).

A palavra bugre, naquele contexto, portanto, pode ser apreendida de duas distintas formas: a primeira, vinculada a uma atribuição identitária coletiva, não restritiva aos Coroados, mas relacionada aos indígenas tidos como selvagens dos sertões brasileiros, embora no Rio Grande do Sul tenha se mantido como um etnônimo exclusivo daqueles, conforme o excerto anteriormente escrito. Outra forma é caracterizada pela individualização do processo de significação/ adjetivação do termo, vinculado a indivíduos com experiências específicas, como a vivenciada por Luís Bugre. Esses significados, mesmo que distintos em suas construções sociais, podiam ser vividos concomitantemente. Detenhamo-nos no segundo processo, o de individualização do termo. Quais experiências compartilharam os indivíduos que passaram a ser referidos como bugres?

Um primeiro ponto em comum diz respeito ao fato de todos esses indivíduos terem circulado entre universos estruturalmente distintos, porém, em um contexto específico. Entretanto, o fizeram, de modo geral, de uma forma inicialmente imposta pela condição de sequestrados. Esses personagens foram furtados do convívio de seus grupos de origem por terem sido capturados. Deste modo, tiveram como experiência a circulação em domínios culturais diversos e, a partir disto, absorvendo a capacidade de assumir a função de intermediários. A categoria de intermediário cultural apresenta-se como primordial para perceber certas situações em que as interações entre grupos culturalmente distintos gerou necessidade de reordenação das formas de negociação e disputas entre os envolvidos. 
Estes indivíduos que conseguiram transpor essas "barreiras" foram caracterizados como mediadores em momentos e formas diversas. ${ }^{18}$

Em segundo lugar, nenhuma dessas pessoas pôde retomar sua vida ordinária sem a marca da experiência com "o outro", levaramna, inclusive, em seus nomes: Luís Bugre, Maria Bugra, Jacó Bugre. Esses personagens passaram a ocupar lugares marginais, uma espécie de retorno gauche às suas respectivas sociedades de origem. Essa informação torna-se mais exata no caso dos alemães, visto que deles temos mais condições de acessar, através das fontes escritas, os sentimentos causados por aquela situação. Mas por considerarmos a experiência comum, podemos deduzir quais as emoções que Luís pode ter experimentado. Tanto Jacó quanto Luís não abriram mão de manter os laços com sua cultura, mesmo afastados dela. O primeiro encontrava em suas reminiscências da civilização um lugar para buscar conforto nos momentos de tristeza. O segundo, sempre que podia, mesmo quando muito moço, retornava às matas em busca dos seus. Mas ambos aprenderam a ser um pouco do "outro", de modo a negociar suas identidades em busca de vantagens naquela situação.

Portanto, não se nasce bugre, estes são feitos/criados na história. O objetivo não é interrogar a palavra bugre, mas a "gênese social imprecisa e com uma história”, conforme destaca E. P. Thompson (1981). Nesse mesmo sentido, Wilde (2003) problematiza as categorias isoladas e estanques sobre os Guarani missioneiros em seus estudos na Bacia do Rio da Prata. Afirma que algumas categorias podem expressar não um grupo específico, mas um conjunto de representações sobre o imaginário dos próprios atores que viveram aquela situação, dentro de "[...] un espacio semántico de 'no pertenencia', de movilidad y oposición al orden estabelecido [...]” (2003, p. 122). Do mesmo modo, a categoria bugre parece relacionar-se também com o universo simbólico (BACZKO, 1991), em que se observa um arcabouço imaginativo do qual se nutria a ideia sobre o "outro" por parte dos indivíduos que não tiveram a experiência do contato na forma de sequestro. Este problema pode ser vislumbrado através das escolhas narrativas do Monsenhor, que, ao escolher a terceira pessoa como perspectiva narrativa de seu romance, pode atribuir sentimentos a personagens aos quais não teve acesso e, assim, fazê-los representativos das impressões dos colonos alemães em geral. 
Estes personagens fizeram-se, portanto, intermediários culturais. Papel que apresentava importância significativa naquele momento, pois eram capazes de fazer circular informações, pessoas, objetos e todo um universo imaginativo entre os mundos que se cruzavam. Se pensarmos especificamente em Luís Bugre, percebemos como sua história nos faz percorrer distintos universos: os da colonização alemã e italiana, os Coroados e, por fim, a condição distinta enquanto bugre. Assim, a identidade daquele sujeito foi construída sob diversos parâmetros, mostrando-se múltipla e versátil conforme as necessidades que encontrou em seu percurso. A emergência social destes "bugres" pressupõe uma conjunção social em que a mescla ultrapassa o universo biológico e se entranha nas formas de vida produzidas em contextos de interação, forçados ou não, entre grupos social e culturalmente distintos. A experiência como "bugres" significa o próprio entrelaçamento dos universos através das experiências concretas dos sujeitos históricos em lidar com essa situação; é o resultado da incerteza sobre o produto de um encontro.

\section{Considerações finais}

Portanto, no século XIX, na interação entre colonos alemães e índios Coroados, a expressão bugre não dizia respeito apenas aos indígenas, mas poderia designar uma certa indianização de pessoas que partilharam aquela experiência e, no caso do indígena "germanizado", referia-se a uma estigmatização de sua procedência. Note-se aqui a distância que tomamos da categorização sugerida por Roberto Cardoso de Oliveira (1976), em que bugre constitui, nas palavras de Darcy Ribeiro, “[...] uma categoria social engendrada pela fricção interétnica” (1976, p. 09). Assim, tratar-se-ia de um nome pejorativo designado, no máximo, aos descendentes dos indígenas que teriam "perdido" parcelas significativas de sua cultura anterior. No caso aqui tratado, bugre também pode ser apreendido como uma categoria social, porém, não restritiva a um grupo étnico (índios), mas como uma categoria que emerge de uma experiência comum em que membros de ambos os grupos podem ser identificados sob sua 
tutela. Não há "perdas" culturais, mas sim uma experiência cultural na qual indivíduos passam a ser ressignificados nas sociedades da qual fazem parte e também adquirem novas formas de conceber as relações de alteridade. Infelizmente, mais uma vez nos é impossível acessar a forma como os indígenas perceberam esses "outros" dentro de seu corpo social, se também criaram uma categoria para inseri-los, ou se aproveitaram uma pré-existente.

Nosso objetivo em destacar a categoria bugre reside na necessidade de não endossar lugares comuns ao tratarmos da temática indígena no sul do país. Mesmo que inacabada ou incompleta, a categoria bugre pode dar conta de potencializar a compreensão do contexto anteriormente tratado. Ser bugre no Rio Grande do Sul do século XIX pode ser, assim, compreendido como o resultado de uma relação que foi capaz de significar um modo excepcional de fazer parte da história, demonstrando que os processos de formações identitárias são contextuais.

\section{THE HISTORY AT AS VÍTIMAS DO BUGRE, OR HOW TO BECOME BUGRE IN HISTORY}

Abstract: This article will address the overlap in territorial, cultural and political rights of Germans in Kaingang and Vale do Rio dos Sinos, Rio Grande do Sul, during the mid-nineteenth century. The first forms of approximation between both, since the observation until the beginning of a shared state of fear, which became the result of actual combat. We will seek to explain the motivations that led these individuals to more complex situations that arose this superposition worlds. Keywords: Indigenous History. Kaingang indians. German immigration. Bugres. Individual trajetories.

\section{Notas}

${ }^{1}$ Este artigo é uma versão reduzida do segundo capítulo de minha dissertação de mestrado Coroados a Kaingang: as experiências vividas pelos indios num contexto de imigração no século XIX, defendida no Programa de Pós-Graduação em História da Universidade Federal do Rio Grande do Sul.

${ }^{2}$ A sociedade Kaingang é ligada à família linguística Jê do Tronco Macro-Jê. Neste trabalho, optamos por utilizar o etnônimo Coroados para fazer referência 
a este grupo, de modo a evidenciar também a historicidade das formas de identificação do mesmo.

${ }^{3}$ Relatório do Inspetor da Colônia de São Leopoldo, José Thomaz de Lima, de 17 de dezembro de 1829. APERGS. Revista do Museu e do Arquivo Público do Rio Grande do Sul. Número 15-16, setembro e dezembro de 1924, p. 233.

${ }^{4}$ Relatório do Diretor das Colônias João Daniel Hilldebrand, 1854. APERGS. Revista do Museu e do Arquivo Público do Rio Grande do Sul. Número 15-16, setembro e dezembro de 1924, p. 382-383.

${ }^{5}$ Gansweidt nasceu na Alemanha, em 1874. Estudou na Universidade de Louvaine na Bélgica, mas finalizou sua formação no Seminário Episcopal de Porto Alegre. Aqui, trabalhou em diversas localidades de origem teuto. Foi eleito Cônego Honorário em 1929 e Monsenhor em 1948. Dedicava-se às letras e produziu poemas, contos e dois romances: As vítimas do Bugre e Chico Monge e seu Bando.

${ }^{6}$ Em alemão, Luis Buger und die opfer seiner rache (1929), cuja tradução feita por mim, é Luís Bugre e a vítima de sua vingança. É a versão em português que utilizamos neste trabalho que foi traduzida pelo Irmão Eugênio Damião (1946).

${ }^{7}$ O Arcebispo de Porto Alegre, D. João Becker - religioso de grande influência na política do sul do país - emigrou da região de Trier, na Alemanha, quando tinha oito anos. Chegou em São Vendelino em 1878. Ao tomar os manuscritos colhidos por Mons. Gansweidt, pensou ter em mãos a história que o contemplaria com um lugar cativo na Academia Brasileira de Letras (GANSWEIDT, 1946, introdução). ${ }^{8}$ Mapa Estatístico da chegada de imigrantes alemães. AHRS. Fundo Colonização, Livro III, p. 34.

${ }^{9}$ Conforme os apontamentos do agrimensor Pierre Alphonse Mabilde ([18361866] 1983, p. 97), os meninos coroados iam morar muito cedo sozinhos, por volta dos onze ou doze anos. Somente quando completavam entre vinte e vinte e quatro anos que lhes era concedido, se ainda não possuíssem mulheres, que morassem com outros homens solteiros (DORNELLES, 2011, p. 37-46).

${ }^{10}$ A maior parte das referências sobre a vida de Luís Antônio da Silva Lima apresentam-se em memórias de colonos ou cartas. Até o presente momento acessei, apenas, as publicadas.

${ }^{11}$ Relatório 13/04/1968 - Relatório com que o Exmo. Sr. Dr. Francisco I. Marcondes Homem de Mello passou a administração d'desta Província ao Excelentíssimo Senhor Doutor Joaquim Vieira da Cunha, $1^{\circ}$ Vice-presidente. Porto Alegre: Typographia do Jornal do Commercio, 1968, p. 30.

${ }^{12}$ Idem.

${ }^{13}$ Correspondência de 19/05/1853 - Correspondência de Felipe José de Souza ao Presidente da Província de São Pedro do Rio Grande do Sul. AHRS. Aldeia de Vacaria. 299, Maço 2. 


\section{Soraia Sales Dornelles}

${ }^{14} \mathrm{O}$ coronel Serafim de Moura Assis transmitiu essa narrativa ao jornalista e escritor Nicolau Mendes, que publicou esta história no livro O império dos coroados, em 1954.

${ }^{15}$ Luisa Wittman (2007) conclui de maneira similar a respeito dos ataques empreendidos pelos Xokleng às colônias alemãs no estado de Santa Catarina. A busca por ferro mostrava-se também, naquele contexto, como o foco dos indígenas.

${ }^{16}$ GARDELIN, Mário; COSTA, Rovílio. Colônia Caxias: origens. Porto Alegre: Escola superior de Teologia (EST), 1993 e Jornal Folha de Caxias. (números 56 ao 63 - ano I - Caxias do Sul).

${ }^{17}$ Até o presente momento da pesquisa ainda não me foi possível acessar algum dicionários de época que contivesse a palabra "bugre".

${ }^{18}$ Entre os trabalhos que possuem esta abordagem, destaco: BOCCARA, Guillaume. Etnogénesis mapuche: resistência y restructuración entre los indígenas del Centro-Sur de Chile (siglos XVI-XVIII), Hispanic American Historical Review, 79:3 (1999), p. 424-461; WILDE, Guillermo. Prestígio indígena y nobreza peninsular: la inversión de linages guaraníes em las misiones del Paraguay. Jahrbuch Fur Geschichte Lateinamerikas, 2006. p. 119-145.

\section{Referências:}

BACZKO, Bronislaw. Los imaginarios sociales. Buenos Aires: Nueva Visión, 1991. BECKER, Ítala Irene Basile. O indio kaingáng no Rio Grande do Sul. São Leopoldo: UNISINOS, 1995.

DICIONÁRIO Houaiss da língua portuguesa. Rio de Janeiro: Objetiva, 2009.

DORNELLES, Soraia Sales. De Coroados a Kaingang: as experiências vividas pelos índios num contexto de imigração no século XIX. Dissertação (Mestrado). Programa de Pós-Graduação em História da Universidade Federal do Rio Grande do Sul, Porto Alegre: 2011.

GANSWEIDT, Matias José. As vítimas do Bugre. Porto Alegre: Selbach, 1946.

KERBER, Alessander; PADANOV, Cleber Cristiano; PUHL, Paula Regina. Representações étnicas no folhetim Maria Bugra: episódio dos princípios da colonização alemã e a construção da identidade da cidade de Novo Hamburgo. Anos 90. v. 14, n. 26, Porto Alegre, dez. 2007.

LAROQUE, Luís Fernando da Silva. Lideranças Kaingang no Brasil meridional (1808-1889). In: Pesquisas, 56, 2000. 
MABILDE, Coronel Affonso P. T. Apontamentos sobre os indígenas selvagens da nação "Coroados" que habitam os sertões do Rio Grande do sul. In: Annuario do Estado do Rio Grande do Sul. Porto Alegre, 1893.

MONTEIRO, John M. Tupis, tapuias e historiadores: estudos de História indígena e do indigenismo. Tese de Livre Docência. Campinas: Unicamp, 2001.

O OliveIRA, Roberto Cardoso de Oliveira. Do indio ao bugre: o processo de assimilação dos Terêna. Rio de Janeiro: Francisco Alves Ed, 1976.

POLONI-Simard, Jacques. Redes y mestizaje: propuesta para el análisis de la sociedad colonial. In: BOCCARA, Guillaume; GALINDO, Sylvia (Eds.). Lógicas Mestiza em América. Temuco, Chile: Instituto de estúdios indígenas, 1999. p. 113-137

PRATT, Mary Louise. Os olhos do império: relatos de viagem e transculturação. Bauru: EDUSC, 1999.

ROSA, Rogério Réus Gonçalves da. Lenda e mito do cacique Nonohay: guerra e vingança Kaingague no fio do tempo. In: KERN, Arno et al. (Org.). Povos Indígenas. Passo Fundo: Méritos, 2009, p. 137-159.

THOMPSON, Edward Palmer. A miséria da teoria, ou, um planetário de erro uma crítica ao pensamento de Althusser. Rio de Janeiro: Jorge Zahar Ed, 1981.

WILDE, Guillermo. Orden y ambiguidad em la formación territorial Del Rio de la Plata a dines del siglo XVIII. In: Horizontes Antropológicos, 2003, ano 9, n. 19, p. 105-135.

WITTMANN, Luisa Tombini. O vapor e o botoque: imigrantes alemães e índios Xokleng no Vale do Itajaí/SC (1850-1926). Florianópolis: Letras Contemporâneas, 2007.

Recebido em: 28/10/2011.

Aprovado em: 12/12/2011. 